Fanum

Sociológico

\section{Forum Sociológico}

Série II

39 | 2021

Covid-19: Acesso a direitos, desigualdades sociais e (re)arranjos institucionais no controle da pandemia em Portugal e no Brasil

\title{
A Covid-19 e o controle dos corpos : Novas justificativas para o medo do outro
}

Covid-19 and body control: New reasons for the fear of the other

Beatriz Fernanda Carvalho, Heloisa Alexandre Cizeski, Stephanie Tomé Lobozzo Dower, Inayara Santos Sampaio e Bárbara Pozza Scudeller

\section{OpenEdition}

Journals

Edição electrónica

URL: https://journals.openedition.org/sociologico/10015

DOI: 10.4000/sociologico.10015

ISSN: $2182-7427$

Editora

CICS.NOVA - Centro Interdisciplinar de Ciências Sociais da Universidade Nova de Lisboa

Edição impressa

Paginação: 31-41

ISSN: 0872-8380

\section{Refêrencia eletrónica}

Beatriz Fernanda Carvalho, Heloisa Alexandre Cizeski, Stephanie Tomé Lobozzo Dower, Inayara Santos Sampaio e Bárbara Pozza Scudeller, «A Covid-19 e o controle dos corpos : Novas justificativas para o medo do outro», Forum Sociológico [Online], 39 | 2021, posto online no dia 23 novembro 2021, consultado o 29 março 2022. URL: http://journals.openedition.org/sociologico/10015 ; DOI: https:// doi.org/10.4000/sociologico.10015 


\title{
A COVID-19 E O CONTROLE DOS CORPOS: NOVAS JUSTIFICATIVAS PARA O MEDO DO OUTRO* COVID-19 AND BODY CONTROL: NEW REASONS FOR THE FEAR OF THE OTHER
}

https://doi.org/10.4000/sociologico. 10015

\section{Beatriz Fernanda Carvalho}

Universidade de São Paulo, Instituto de Arquitetura e Urbanismo, São Carlos, São Paulo, Brasil. ORCID: https://orcid. org/0000-0002-1045-3228

Heloisa Alexandre Cizeski

Universidade de São Paulo, Instituto de Arquitetura e Urbanismo, São Carlos, São Paulo, Brasil. ORCID: https://orcid. org/0000-0002-0558-2156

Stephanie Tomé Lobozzo Dower

Universidade Estadual Paulista, Faculdade de Ciências e Tecnologia, Departamento de Planejamento, Urbanismo e Ambiente, Presidente Prudente, São Paulo, Brasil. ORCID: https://orcid.org/0000-0001-6730-8710

Inayara Santos Sampaio

- Universidade de São Paulo, Instituto de Arquitetura e Urbanismo, São Carlos, São Paulo, Brasil. ORCID: https://orcid. org/0000-0002-0334-9596

Bárbara Pozza Scudeller

Universidade de São Paulo, Instituto de Arquitetura e Urbanismo, São Carlos, São Paulo, Brasil. ORCID: https://orcid. org/0000-0003-2859-7884

\section{Resumo}

A pandemia da covid-19 resultou na imposição de medidas drásticas de distanciamento socia em países do mundo inteiro, de modo que cada nação optou responder ao vírus da forma que considerou adequada, levando a atuação no controle dos corpos a consequências distintas. No Brasil, as políticas de distanciamento social foram impactadas por fatores resultantes da crise social urbana, aumentando a vulnerabilidade de um grupo específico da população. Ademais, o medo do contágio aqui é associado à insegurança, desenvolvendo crises que aceleram processos já em curso. Esse artigo procura, nesse sentido, discutir a construção dos processos individualistas que resultam no sentimento de medo do outro (pela origem do outro e origem do medo) por micropoderes que, articulados ao Estado e políticas governamentais, naturalizam dispositivos de vigilância, evidenciando sistemas de biocontrole e desdobramentos desse regime nas relações sociais sob o contexto pandêmico no Brasil.

Palavras chave: Covid-19; Medo do outro; Controle dos corpos; Biopolítica

\begin{abstract}
The Covid-19 pandemic resulted in the imposition of drastic measures of social detachment in countries around the world, so that each nation chose to respond to the virus in the way it considered appropriate, taking action to control bodies with different consequences. In Brazil, social distance policies were impacted by factors resulting from the urban social crisis, increasing the vulnerability of a specific group of the population. In addition, the fear of contagion here is associated with insecurity, developing crises that accelerate processes already underway. This article seeks, in this sense, to discuss the construction of individualistic processes that result in the feeling of fear of the other (by the origin of the other and the origin of fear) by micropowers that, articulated to the State and government policies, naturalize surveillance devices showing biocontrol systems and the consequences of this regime in social relations under the pandemic context in Brazil.
\end{abstract}

Keywords: Covid-19; Fear of the other; Control of bodies; Biopolitics

\footnotetext{
* Artigo desenvolvido em dezembro de 2020.
} 


\section{O marco histórico da covid-19}

O ano de 2020 foi historicamente marcado pelo SARS-CoV- ${ }^{1}$, um vírus de transmissão leve e rápida que pode causar desde sintomas leves de gripe até quadros graves de infecção e insuficiência respiratória. A covid-19 (Corona Virus Disease 2019), como ficou conhecida, surgiu em Wuhan, na China, no final de 2019, e logo em seguida foi capaz de parar o mundo durante alguns meses. Em 11 de março de 2020, a Organização Mundial da Saúde decretou o estado de pandemia ${ }^{2}$. O que se viu em seguida foram países fechando suas fronteiras e companhias áreas cancelando seus voos nacionais e internacionais. Com o constante aumento no número de casos e de mortes pela covid-19, cidades inteiras decretaram lockdown. Aglomerações em espaços públicos foram proibidas, escolas foram fechadas, estabelecimentos comerciais e de serviços passaram a funcionar em horário reduzido e até toques de recolher foram decretados.

Apesar de os coronavírus não serem comuns entre os seres humanos, a forma emergencial encontrada para conter a sua rápida propagação foi semelhante à adotada para outros vírus: o distanciamento social. Porém, embora tenhamos presenciado outras pandemias no século 21 , a geração atual nunca presenciou uma cujo vírus tenha circunstâncias de transmissão tão fáceis como as do vírus SARS-CoV-2, capaz de pressionar os governos nacionais a determinarem medidas drásticas de distanciamento social. Nos últimos meses, uma "segunda onda" de casos e de mortes vem surgindo na Europa e na América do Norte, mas a proximidade da aplicação das vacinas recentemente aprovadas pelas agências reguladoras em países como Inglaterra, Rússia, Estados Unidos, México, China e Portugal ${ }^{3}$ alimenta ainda mais a esperança de que a pandemia possa estar sob controle no final de 2021.

De qualquer forma, as decisões que tomarmos ao longo dos anos de 2020 e 2021 moldarão as próximas décadas da História Mundial. Como observa Harari (2020), sob o ponto de vista biológico, não é interessante para os vírus atingirem um alto grau de letalidade; afinal eles precisam de corpos hospedeiros para permanecerem vivos, ou seja, a maioria de nós sobreviverá e as decisões que tomarmos agora para conter a pandemia, seja nos sistemas de saúde, seja na economia, na política e na cultura, permanecerão mesmo após o término dela. Segundo o autor:

Ao escolher entre as alternativas que se apresentam, devemos nos perguntar não apenas como superar a ameaça imediata, mas também que tipo de mundo habitaremos uma vez passada a tempestade. Sim, a tempestade passará, a humanidade sobreviverá, a maioria de nós ainda estará viva - mas habitaremos

um mundo diferente. (Harari, 2020, p. 15)

Além da crise no sistema de saúde pública e privada, as medidas rígidas de distanciamento social fazem se aproximar também crises graves no sistema econômico, social e cultural. Para nós, a importante contribuição que Harari (2020) traz para o ponto de partida deste trabalho é a de que momentos de crise tendem a acelerar processos históricos em curso. Segundo o autor, "muitas medidas emergenciais de curto prazo se tornarão parte da nossa vida. Essa é a natureza das emergências: elas aceleram processos históricos" (p. 15).

Ao longo deste ano de 2020, vimos muitos processos sociais, econômicos, políticos, culturais, educacionais e tecnológicos serem acelerados com a pandemia da covid-19 e a consequente necessidade de distanciamento social: intensificação do uso de plataformas de telecomunicações, necessidade de disponibilização de redes de internet Wi-Fi gratuitas para toda a população, trabalho por homeoffice e ensino remoto e/ou EaD. Isso apenas na tentativa de elencar algumas das consequências que afetaram diretamente a dinâmica do nosso dia a dia.

Veja que todas essas mudanças já se faziam presentes em nossas vidas antes da pandemia. A observação que se coloca é que, a partir deste cenário de crise sanitária, novas medidas passaram a fazer parte da nossa vida muito rapidamente. Processos que talvez levariam cerca de dez anos para se consolidar passaram a fazer parte da nossa rotina diária em menos de um ano (Harari, 2020).

Perante tantos processos que foram acelerados - e, inclusive, intensificados - com a pandemia, para nós um deles salta aos olhos: o medo do outro. Bauman (2014) define o outro como sendo "um vizinho, um transeunte, um vadio, um espreitador e, em última instância, qualquer estranho" (p. 72). 0 outro é o não eu. Mas os vírus nos colocam perante nossa própria contradição: apesar de sermos outro para os outros, somos iguais. O vírus causador da covid-19 contamina sem distinguir os corpos, pois todos nós estamos fadados às mesmas condições biológicas de contaminação por um vírus. Porém, essa falta de distinção entre os corpos pelo vírus faz ecoar em nós uma perturbadora constatação: é preciso temer o outro.

As medidas de distanciamento social nos lembram o tempo sobre nossa própria constatação: o outro significa uma potencial ameaça à minha sobrevivência. Afinal, o vírus da covid-19, assim como outros vírus respiratórios, propaga-se através da proximidade com o outro. Temer o outro se transformou em uma forma de preservar a vida.

Mas o medo do outro não é algo novo, ele não veio com a pandemia, foi apenas agravado por ela. Os mecanismos de vigilância e controle dos corpos, 
por exemplo, já existiam desde outras epidemias, como a Gripe Espanhola e a Peste Negra. Nem mesmo a vigilância realizada pelos dispositivos eletrônicos pessoais foi algo que surgiu com a pandemia. Os nossos smartphones e smartwatches contam com recursos de monitoramento já há alguns anos, como por exemplo, aplicativos de geolocalização - como Google Maps - e de acompanhamento da sua qualidade de saúde - como Health.

Buscando especular sobre este cenário pandêmico e pós-pandêmico, algumas questões se colocaram para nós e que buscaremos aqui discutir: há alguma possibilidade de revertermos essa tendência do medo do outro? Se esses processos já existiam, com o que a pandemia vem contribuir? 0 mundo pós-pandêmico será um mundo mais individualista? Ou podemos esperar algum movimento como contrapartida?

\section{O dispositivo foucaultiano e a construção do não eu}

Para compreendermos a razão dessas questões, entre as origens do outro e as origens do medo, julgamos pertinente retomar o conceito de dispositivo em Michel Foucault e de sua relação com o ser sujeito no mundo. Mais do que o poder, é o tornar-se sujeito objetivo geral de problematização filosófica do autor (Foucault, 1995) que Deleuze enfatiza na afirmação de um interesse pelas condições.

Ele [Foucault] não faz uma história das mentalidades, mas das condições nas quais se manifesta tudo o que tem uma existência mental, os enunciados e o regime de linguagem. Ele não faz uma história dos comportamentos, mas das condições nas quais se manifesta tudo o que tem uma existência visível, sob um regime de luz. Ele não faz uma história das instituições, mas das condições nas quais elas integram relações diferenciais de forças, no horizonte de um campo social. Ele não faz uma história da vida privada, mas das condições nas quais a relação consigo constitui uma vida privada. Ele não faz uma história dos sujeitos, mas dos processos de subjetivação [...]. (Deleuze, 2005, p. 124)

Por essa perspectiva, dispositivo implica o conjunto de elementos operantes na constituição da objetividade e da subjetividade dos sujeitos. Em entrevista à revista francesa Ornicar?, em 1977, Foucault concilia no dispositivo elementos de duas naturezas distintas: a dita (explícita, como nos discursos) e a não dita (implícita, como nas práticas sociais), cujas funções assumidas nas relações que estabelecem entre si são impermanentes - isto é, um discurso pode, em certa situação, "aparecer como programa [declarado] de uma instituição", e em outra, como coisa que "permite justificar e mascarar uma prática que permanece muda" (Foucault, 2019 , p. 364). Ainda na visão do autor, o dispositivo surge enquanto resposta estratégica a um problema de determinado momento histórico, conduzindo o campo de forças no qual se situa em direção a seus objetivos, como veremos brevemente a seguir.

Em Vigiar e Punir (Foucault, 1999a), Foucault se dedica ao estudo das práticas punitivas, desde os suplícios, aplicados no século XVI, até a consolidação e legitimação do sistema prisional, a partir do século XVIII. Os discursos, tecnologias e instituições que envolvem essas práticas assinalam, respectivamente, aquilo que se chama dispositivo de soberania e dispositivo disciplinar. Na transição entre ambos, o espetáculo da punição desaparece, e desaparece também o corpo como "alvo principal da repressão penal". O poder se desloca da lógica de posse para a modesta lógica do "adestramento". Aí se infiltra nos "grandes aparelhos do Estado", modificando seus mecanismos e impondo-Ihes seus processos (Foucault, 1999a). É através do olhar hierárquico e da sanção normalizadora que o poder disciplinar produz o sujeito-obediente.

Nesse sentido, o modelo de vigilância presente nas sociedades disciplinares é comparado, por Foucault, ao Panóptico de Bentham: um projeto de construção carcerária no qual os detentos, incapazes de saberem se estão sendo vigiados, mas conscientes da possibilidade permanente de o serem, reproduzem em si mesmos os mecanismos de controle e garantem o exercício automático do poder (Foucault, 1999a). Um elemento fundamental na análise foucaultiana sobre o panóptico, contudo, é a percepção de que o poder disciplinar não se limita ao sistema penal, mas se difunde em diversas instâncias da vida. Ao lado do olhar hierárquico, a sanção normalizadora preenche as lacunas deixadas pela lei, reprimindo pequenos comportamentos que escapam à gravidade das infrações maiores e garantindo que os sujeitos, em suas crenças, desejos e ações, se dediquem ao cumprimento do padrão de "normalidade".

É nessa sociedade disciplinar, pois, que se substitui a figura do infrator pela figura do delinquente: mais do que no próprio ato criminoso, o crime existe, antes, naquele que o comete; mais do que as circunstâncias do crime, importa conhecer a história de vida do criminoso, sua posição social, sua educação - a origem de seus desvios de normalidade -, para que o sistema disciplinar possa corrigi-los. A prisão, no entanto, enquanto forma de ressocialização dos indivíduos, enquanto punição corretiva, nunca se realizou, e para Foucault, nunca foi esse seu objetivo. Segundo o autor, ela é concebida como um instrumento de dominação a partir do qual a classe dominante, pelo abuso de poder sobre os prisioneiros, produz indivíduos 
coléricos e assim os estigmatiza, desmoralizando uma parcela específica e selecionada da população a ser considerada, no imaginário coletivo, como perigosa ou "fadada à desordem" (Foucault, 1999a, p. 229). O medo, então, é produzido e promovido pelo sistema prisional para "legitimar, justificar e endurecer o controle social" (Gonçalves, 2018, p. 277) que garante à classe dominante a manutenção de seu poder.

Se entendemos, então, o poder disciplinar como não restrito às práticas estatais punitivas, mas também envolvendo um conjunto de micropoderes que, articulados ao Estado, percorrem toda a estrutura social, como pensar o campo das relações sociais? Isto é, de que forma as instituições panópticas exercem sua dominação sobre corpos "marcados" para além do ambiente panóptico? Ou, de que forma os corpos "não marcados" se tornam instrumentos de difusão do controle panóptico sobre os delinquentes-criados, através das relações cotidianas? Embora, na atualidade, não se possa falar exatamente em sociedade disciplinar, seus dispositivos não desapareceram com a modificação dos mecanismos de poder. Na segunda metade do século XVIII, Foucault identifica o surgimento de uma nova tecnologia, a biopolítica, que, apesar de deslocar o foco da docilização do corpo individual ("homem-corpo") para o controle do corpo biológico em escala populacional ("homem-espécie"), se apropria da normalização disciplinar e a fortalece na configuração de dispositivos mais complexos - os dispositivos de segurança. A biopolítica, portanto, tem como função maior a gestão da vida e, ao contrário do direito soberano que "faz morrer ou deixa viver", é um direito "de fazer viver e de deixar morrer" (Foucault, 2005).

Segundo Danner (2011), a morte, no biopoder, só pode ser aceita na medida em que se proponha "eliminar o perigo biológico" para o fortalecimento de um grupo definido também em termos biológicos. O racismo se torna, através dessa nova tecnologia de poder, um mecanismo de Estado que não só estabelece uma fragmentação no conjunto da população, subdividindo-a em raças - diferenciadas, hierarquizadas e qualificadas -, como permite uma relação positiva entre morte e vida:

[...] quanto mais você deixar morrer, mais, por isso mesmo, você viverá. [...]. A morte do outro não é simplesmente a minha vida, na medida em que seria minha segurança pessoal; a morte do outro, a morte da raça ruim, da raça inferior (ou do degenerado, ou do anormal), é o que vai deixar a vida em geral mais sadia; mais sadia e mais pura. (Foucault, 2005, p. 305)

Bauman (2014), ao recuperar o conceito de ban-óptico de Didier Bigo, nos traz um exemplo de dispositivo pós-panóptico em operação nas sociedades ocidentais contemporâneas, que, embora não se associe diretamente ao extermínio biopolítico, é, sem dúvida, parte de sua promoção. O dispositivo ban-óptico identifica todo indivíduo ou grupo de indivíduos a quem não se pode confiar a manutenção e a reprodução da "ordem", a autovigilância em relação ao cumprimento de uma série de comportamentos esperados, e que, portanto, necessitam de "ajuda mecânica" para se alinharem - indivíduos, esses, não confiáveis seja pela falta de acesso às condições que assim os tornem, seja pelo próprio desejo de permanecerem ou tornarem-se independentes dos padrões comportamentais. O ban-óptico seleciona, então, no discurso de preservação da ordem, os potenciais a se deixar morrer.

Exposta esta breve contextualização, fundamentada sobretudo no pensamento foucaultiano, e que não se desafia tratá-lo em toda sua densidade, voltamos à questão inicial. De que forma as macro e micropolíticas em vigor constituem o "regime de verdade" a partir do qual é possível reconhecer a si, e a partir do qual, portanto, é possível reconhecer ao outro como um não eu que se deve temer? De que forma, enfim, a pandemia da covid-19 atua sobre esse "regime de verdade" e o enfraquece ou potencializa? Como vimos, dos dispositivos disciplinares, com a instituição da figura do delinquente, aos dispositivos de segurança, com a racialização dos corpos e a definição daqueles "inferiores", há construída e naturalizada uma ameaça que se atribui a grupos específicos. Nos próximos capítulos deste ensaio, tentamos analisar se se configuram, e em que medida, os contornos de um outro não eu (ou de uma nova "ameaça"), suscitados pelo contexto pandêmico.

\section{Naturalização da vigilância como resposta ao medo do outro}

Em tempos da pandemia da covid-19, as políticas governamentais frente à doença evidenciam como o biocontrole e seus dispositivos acabam modelando as ações entre corpos, sobretudo como os corpos do outro irão se relacionar no espaço público. Se já existia uma distinção entre grupos e uma tendência mundial ao individualismo, isso passou a ser intensificado pelo isolamento e distanciamento social - medida emergencial adotada para conter o avanço da covid-19 - e, especialmente, pelo medo do contágio.

Como mostra Carlos (2020), a forma de combate à covid-19 tem se dado muito mais no âmbito social que no da biomedicina. Como o SARS-CoV-2 é um vírus novo nos estudos científicos, no início da pandemia ainda havia muitas dúvidas sobre o modo de contágio da doença. Com o avanço da doença e dos estudos, verificou-se a capacidade do vírus de 
contaminar o ar; assim, a quarentena foi o método definido, pela Organização Mundial da Saúde (OMS), como o mais eficaz - em primeiro momento - no combate à doença, e medidas rígidas de distanciamento social foram aplicadas em diversos países como meio de controlar a propagação do vírus.

A construção do pensamento de Preciado (2020) evidencia a forma como as ações políticas frente à pandemia não são meramente científicas, mas sobretudo ações de biocontrole que definem quais grupos da população receberão zelo e quais deliberadamente serão excluídos. Apesar de o SARS-CoV-2, uma única mutação viral, ser a causa desta pandemia, cada nação respondeu de uma forma diferente ao vírus, levando, então, a consequências distintas ${ }^{4}$.

O trabalho de Foucault sobre a biopolítica é, para nós, uma análise histórica das técnicas de "fazer viver e deixar morrer", executadas através dos dispositivos de controle e vigilância dos corpos. Esses dispositivos de controle dos micropoderes operam nos processos de subjetivação do indivíduo e, como consequência, afetam suas práticas comportamentais. A dupla "dispositivos" e "práticas comportamentais" é, então, visível não só entre escalas distintas (quando as relações de poder são verticalizadas), mas também nas relações entre sujeitos (quando as relações de poder são horizontalizadas).

Sintetizando a relação que cada Estado toma frente às epidemias, Preciado (2020, p. 167, tradução nossa) afirma: "diz-me como tua comunidade constrói sua soberania política e te tirei quais formas tomarão suas epidemias e como as afrontas". Essas formas se mostram por meio de políticas de isolamento, de lockdowns ou mesmo pelo negacionismo. Para o autor (Ibidem), se as técnicas governantes estabelecem uma rede de poder, tal rede cobrirá todo território até o corpo individual, controlando, portanto, o corpo social, que também se apresenta como corpo político. Tal forma de poder determina quem sobreviverá, segundo a necropolítica do "fazer viver e deixar morrer", justificada pela soberania e sobrevivência da nação - sob o custo de vidas para normalização do estado de exceção, atualmente vivenciado pela pandemia da covid-195.

No cenário atual, as regras de distanciamento e uso de máscaras são divulgadas a todo momento em propagandas, lembretes nos telejornais e campanhas nas mídias sociais. Mas, implicitamente, o que todos esses lembretes nos avisam é de que o outro pode representar uma ameaça. Talvez seja esta "fragilidade", enquanto um traço comum a todos os humanos frente ao que não controlamos, a causa e a condição dos afetos que se estabelecem hoje: o medo, o tédio, a solidão e a descrença (González, 2020).

Tais sentimentos não são novos na humanidade. $\mathrm{O}$ que propomos discutir é que o cenário pandêmico potencializou esses processos que já vinham se desenvolvendo na sociedade contemporânea. Para Beiguelman (2020), o coronavírus trouxe novos comportamentos e medidas de precaução que culminam em uma aversão ao contato físico, já que é o encontro o causador da difusão do vírus (Simoni, 2020). O espaço público, dado à sua imprevisibilidade, passa, então, a ser um lugar perigoso e contagioso. Os corpos contagiosos precisam ser distanciados social e territorialmente: "O vírus, como nos ensinou Derrida, é, por definição, o estrangeiro, o outro, o estranho" (Preciado, 2020, p. 167; tradução nossa, grifo nosso).

O controle dos corpos, com a justificativa de monitoramento da doença e prevenção de contágio, é amplamente intensificado pelos governos: termômetros e câmeras termais ocupam os lugares de entrada dos estabelecimentos; monitoramento remoto da população, por meio do sinal das torres de companhias telefônicas, é uma prática adotada por gestores públicos e privados para controlar o isolamento. A relação entre o individualismo e o uso da tecnologia, tão característica na cidade contemporânea, exerce grande expressão nesse processo, já que é com ajuda desses novos dispositivos da biopolítica que os mecanismos de controle vão aparecer.

Essa governança, mesmo no cenário pandêmico, mantém sua lógica de combinar propositadamente interesses particulares e políticos, manipulando a "coisa pública em proveito do privado" (Carlos, 2020, p. 12$)^{6}$. No Brasil, políticas de assistência social foram instauradas com o intuito de reservar uma renda mínima à população vulnerável, assegurando o direito à saúde e ao bem-estar das famílias, mas principalmente, com o objetivo de estimular a economia - que seria prejudicada com o fechamento do comércio, aumento do desemprego e consequente diminuição do poder de compra da população.

A criação de tais medidas emergenciais evidencia a preferência do Estado em salvar a economia antes da saúde da própria população. De fato, no momento de criação da política do auxílio emergencial ${ }^{7}$, o poder executivo ainda insistia no discurso negacionista da pandemia, relativizando a crise de saúde pública, propagando fake news sobre recomendações da $\mathrm{OMS}^{8}$ e boicotando tentativas dos poderes municipais e estaduais no controle da propagação do vírus ${ }^{9}$.

Em um país pautado pelo neoliberalismo, as políticas públicas de combate à covid-19 replicam essa lógica segregadora. A tensão entre os grupos sociais é, então, justaposta à distinção entre corpos contagiosos e imunes, intensificando a segregação e hierarquias espaciais do território já existentes. o vírus, ao se apropriar do "rosto" periférico, se torna um instrumento fortalecedor do processo de radicalização da segregação e desigualdade social a 
partir desse "medo do outro". Desse modo, conforma-se uma espacialização da própria pandemia, que exacerba a precarização da vida, de acordo com as possibilidades de enfrentamento: população com menos índice de mortalidade e população com maior índice de mortalidade pelo vírus ${ }^{10}$ (Padua, 2020).

González (2020) e Beiguelman (2020) são enfáticos no risco de naturalização e incorporação dessas práticas de vigilância disseminadas sob o contexto de proteção à vida. Para além de um monitoramento pelo governo, tais práticas podem contribuir para uma mudança nas próprias relações sociais, "afetadas por um desafeto" (González, 2020, p. 141 , tradução nossa).

A covid-19 coloca em pauta uma nova biopolítica, que transforma a vigilância em um procedimento poroso e adentra os corpos sem tocá-los. Seu motor, o mecanismo que coloca essa vigilância em funcionamento, é a administração do medo, a partir da combinação do discurso da segurança pública com o da saúde pública. (Beiguelman, 2020, p. 26)

A busca por segurança é o motivo-chave para termos naturalizado esses dispositivos, pois "a vigilância parece ter um forte motivo de proteção: vigiar para cuidar" (Bauman, 2014, p. 70). Bauman (2014) nos apresenta um outro motivo para tamanha obsessão pelos mecanismos de controle e vigilância:

\footnotetext{
É por essa dupla razão - proteger-nos dos perigos e de sermos classificados como um perigo - que temos investido numa densa rede de medidas de vigilância, seleção, segregação e exclusão. Todos nós devemos identificar os inimigos da segurança para não sermos incluídos entre eles. Precisamos acusar para sermos absolvidos, excluir para evitarmos a exclusão. Precisamos confiar na eficácia dos dispositivos de vigilância para termos o conforto de acreditar que nós, criaturas decentes que somos, escaparemos ilesos das emboscadas armadas por esses dispositivos - e que assim seremos reinvestidos e reconfirmados em nossa decência e na adequação de nossos métodos. (Bauman, 2014, p. 72, grifo do autor)
}

A covid-19, devido à particularidade da situação, impõe a cumplicidade com o monitoramento como uma prerrogativa de sobrevivência (Beiguelman, 2020). Ser rastreado pelo Estado passou, ainda mais, a ser visto como sinônimo de proteção. Desse modo, acabamos nos resignando a uma outra hierarquia social, na qual os sujeitos móveis, não rastreáveis, são os seres "invisíveis" para as políticas públicas de contenção do vírus.
Além desses corpos "invisíveis", a distinção entre os corpos que podem ficar em isolamento, protegidos, e os corpos que, propositadamente, são colocados em risco acentua o tom das divisões entre grupos sociais. Nessa sociedade em que a vigilância e o controle são cada vez mais naturalizados, a cidade se mostra ainda mais monitorada e excludente. Nesse sentido, como apresenta Beiguelman (2020, p. 34) "A coronacity é então, uma cidade mais excludente e mais monitorada", onde as formas de controle via acesso a dados provenientes das redes apontam para uma vigilância distribuída, que relativiza o próprio modelo panóptico de Foucault. Por seu aspecto indolor e invisível, essa vigilância algorítmica atua como se não existisse; despercebida, capta dados que nós mesmos doamos, conscientemente ou não.

Como Rolnik e Wisnik (2020) e Preciado (2020) afirmam, nossos corpos se tornam os novos enclaves de biopoder e as residências as novas células individuais, dentro das quais nos isolamos daquele espaço público do encontro entre os diferentes e entramos em uma nova rede de comunicação virtual e à distância. Se essa nova rede já era um processo em curso com os usos dos aplicativos de monitoramento, sem dúvida foi potencializado devido à pandemia da covid-19 pela necessidade de isolamento social.

Por conta dessa busca por segurança, já nos submetíamos voluntariamente às técnicas e às tecnologias de vigilância. Contudo, como antes indicado, o que hoje observamos com a pandemia é a radicalização de uma tendência já anunciada por Bauman. Em meio a essa sociedade líquida, descrita pelo mesmo autor (Bauman, 2001), os medos se apresentam nebulosos e informes, assim como o vírus da SARS-CoV-2 se apresenta hoje: sabemos que existe e paira entre nós, mas não conseguimos vê-lo a olhos nus. Perante a iminente ameaça de contaminação, sabemos que precisamos de proteção, mas não podemos enxergar exatamente do que e/ ou de quem precisamos nos proteger. Na dúvida, naturalizamos o temor pelos corpos outros, aqueles que não conhecemos. O medo é um sentimento que, assim como o vírus, paira no ar. Para Bauman, ironicamente, o efeito que a presença das medidas de segurança parece gerar é um reforço do sentimento de insegurança; afinal, se eu preciso me assegurar de algo, isso significa que também existe algo que eu devo temer.

Diante desse processo de naturalização da vigilância e monitoramento constantes, fortalecido pelo medo e insegurança do outro, verificamos o reforço das medidas de distinção entre os corpos. Partindo de um cenário pré-existente ao vírus, a individualidade e a segregação se apontam para nós como um comportamento a ser ainda mais reforçado em nossas relações sociais com o outro no mundo pós-pandêmico. Mas ainda seria possível encontrar 
alguma saída a essa tendência? Ou ela se tornará ainda mais irreversível no mundo pós-covid-19?

\section{Os desdobramentos do controle durante a pandemia da covid-19}

Como já apresentado, o mecanismo de controle epidêmico adotado pelo poder público é o isolamento social. Este isolamento, além de contribuir para o agravamento de crises econômicas, com a paralisação de grande parte das atividades produtivas e de consumo, aprofunda o problema do individualismo na sociedade contemporânea. Na perspectiva das relações sociais, a inevitabilidade do distanciamento físico como proteção ao contágio reduz as possibilidades de troca humana e o espaço público se torna mais um espaço de circulação, esvaziado, e menos uma esfera pública do encontro e da experiência coletiva.

Nesse processo, alimentado pela necessidade de preservação individual, a mídia e as redes sociais têm papel fundamental: humanizando o individualismo em defesa do isolamento, reforçam o perigo das interações entre os indivíduos, o que coloca o espaço público sob ameaça (Carlos, 2020). Na mídia, "Os rostos da crise não são, assim, tão literais e as fotos tentam criar empatia ao isolamento, humanizando uma sociedade individualista que vive sob o signo do 'hedonismo de massa'" (Ibidem, p. 11).

Como discute Simoni (2020, p. 25), "Se o vírus causador da pandemia tivesse um DNA, ele traria o gene da sociedade urbana". O individualismo é, então, um aspecto da crise do medo do outro, que é exacerbado pelos dispositivos de segurança biopolítica governamentais, principalmente nesse período pandêmico, acelerando processos políticos-sociais já em curso.

A distinção entre os grupos sociais se intensifica quando verificamos que o acesso a dispositivos tecnológicos é um privilégio, tal qual a possibilidade de exercer um trabalho remoto. De modo desigual, as classes de médio e alto poder aquisitivo podem se isolar em suas células, enquanto as classes de baixo poder aquisitivo ficam expostas ao vírus nos espaços urbanos, sobretudo, por exercerem atividades que exigem a presença física ${ }^{11}$. Com exceção dos profissionais de saúde, que ainda precisam exercer o seu trabalho de forma presencial nos hospitais, laboratórios, centros de pesquisa e postos de saúde, os demais corpos a desempenharem trabalhos presenciais pertencem aos corpos estigmatizados, tidos como o outro.

Figura $2 \triangle$ Transporte público lotado durante a pandemia da covid-19. À esquerda, metrô em São Paulo, à direita, ônibus no Rio de Janeiro.
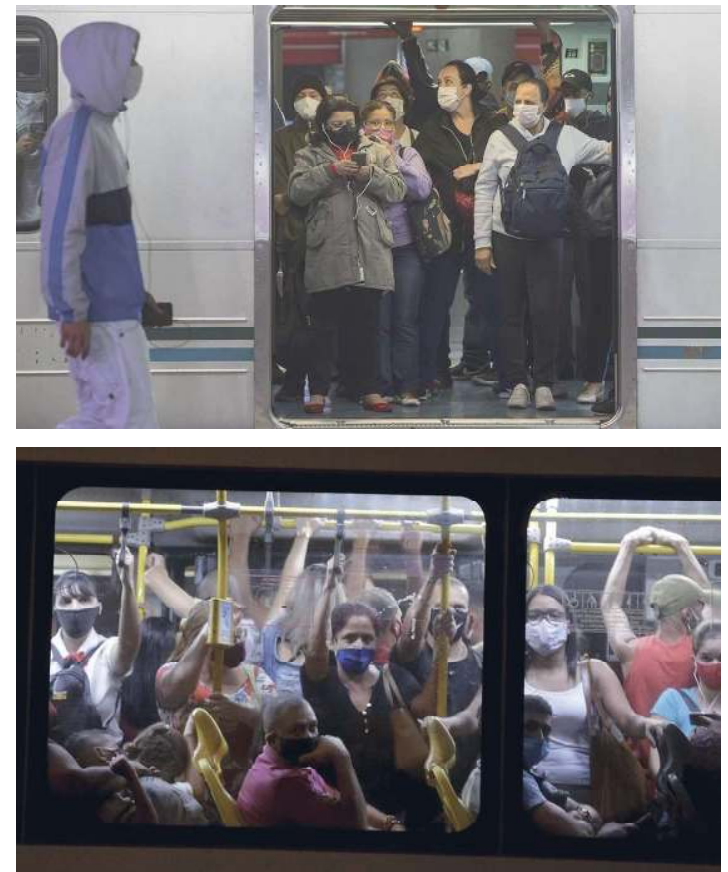

Fonte: O Globo. Edilson Dantas jul. 2020 (esq.); Domingos Peixoto, jun. 2020 (dir.).

Figura $1 \triangleright$ Isolamento de Selayang Baru, área próxima a Kuala Lampur (Malásia), onde foram confirmados casos de covid-19. A partilha de suprimentos entre pessoas não isoladas e isoladas pelas cercas de arame farpado deve receber autorização das forças policiais, preocupadas com o "controle da disseminação do vírus".
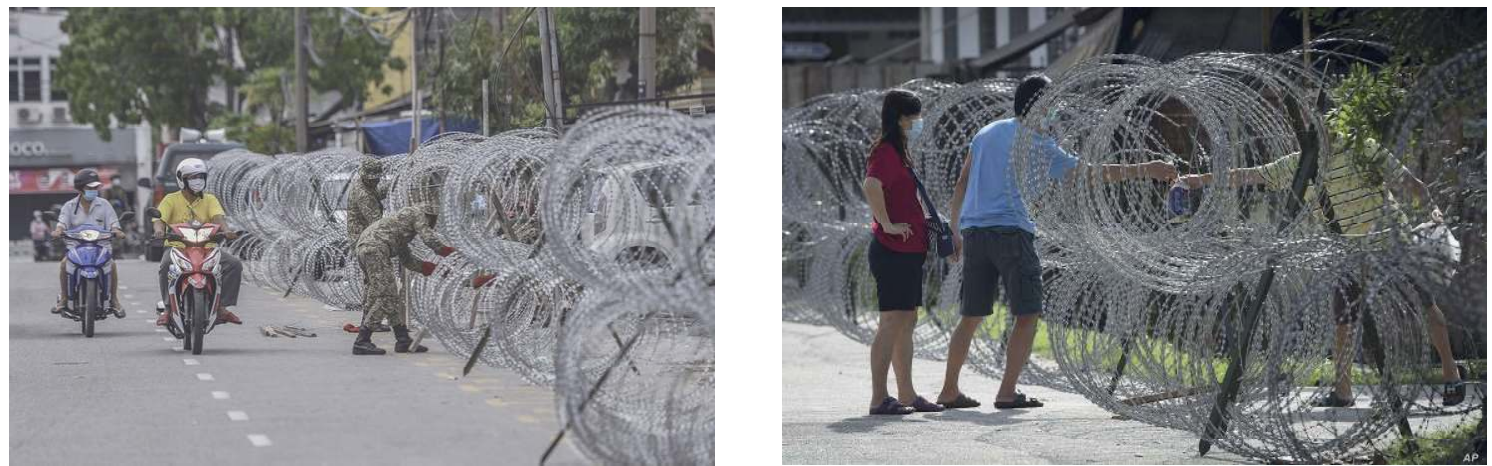

Fontes: Mera Zulyana, abr. 2020 (esq.); Vincent Thian, maio 2020 (dir.). 
Perante a necessidade de isolamento e distanciamento físico, podemos observar também dispositivos físicos, porém artificiais, que intensificam essa tendência ao individualismo e ao medo do outro que são representados por barreiras físicas entre os corpos no espaço público, como "bolhas" de plástico envolvendo usuários de um parque, placas de acetato como proteção entre os consumidores nas mesas de restaurantes e cafés, e até construções de estufas que abrigam a mesa de uma família inteira. Este cenário, que até poucos meses atrás parecia distópico, passou rapidamente - e de forma assustadora - a fazer parte da nossa realidade.

Para nós, a construção de barreiras físicas sob a justificativa de proteção à contaminação do vírus veio muito mais a materializar barreiras sociais e econômicas já existentes. Como é possível observar no compilado de imagens abaixo, os indivíduos que utilizam dessas barreiras não estão ali exercendo atividades essenciais (como os profissionais da saúde) e muito menos aparentam fazer parte do grupo que depende do trabalho presencial em sua renda mensal.

O processo de legitimação das segregações sociais pré-existentes, que antes se mantinha tendenciosamente velado, agora ganha força ao incor- porar uma nova justificativa. Perante as necessidades do ser não outro de demarcar espaços "seguros" para sua sobrevivência, vemos a naturalização radical dos mecanismos de vigilância, segurança e controle dos corpos tidos - de antemão - como contaminados. Os dispositivos de biocontrole passam a modelar a relação entre os corpos, naturalizando o medo do outro e criando uma persona a ser temida. Nesse contexto, os corpos periféricos, já estigmatizados, foram demarcados como o outro, e vistos como ameaça, sendo ainda mais tidos como "perigosos". Reconhecemos que esta se mostra como uma tendência social quase irreversível, que a pandemia da covid-19 vem agravar. Mas haveria alguma saída para tamanha aversão ao outro?

Segundo Rolnik e Wisnik (2020), nos locais onde o Estado exclui as populações socialmente periféricas, surgem movimentos de resistência de corpos em vulnerabilidade social e sanitária. No Brasil, lugar em que o Estado se faz duplamente ausente - não só no negacionismo, como na estigmatização dos corpos socialmente periféricos -, observamos redes comunitárias, criadas a partir de movimentos de autogestão, que fornecem alimentos, produtos de higiene pessoal, assistência à saúde e - principalmente - informação sobre a pandemia e meios de prevenir o contágio.

Figura $3 \triangleright$ Alternativas "criativas" para o público continuar frequentando parques e restaurantes mesmo diante da necessidade de distanciamento social.
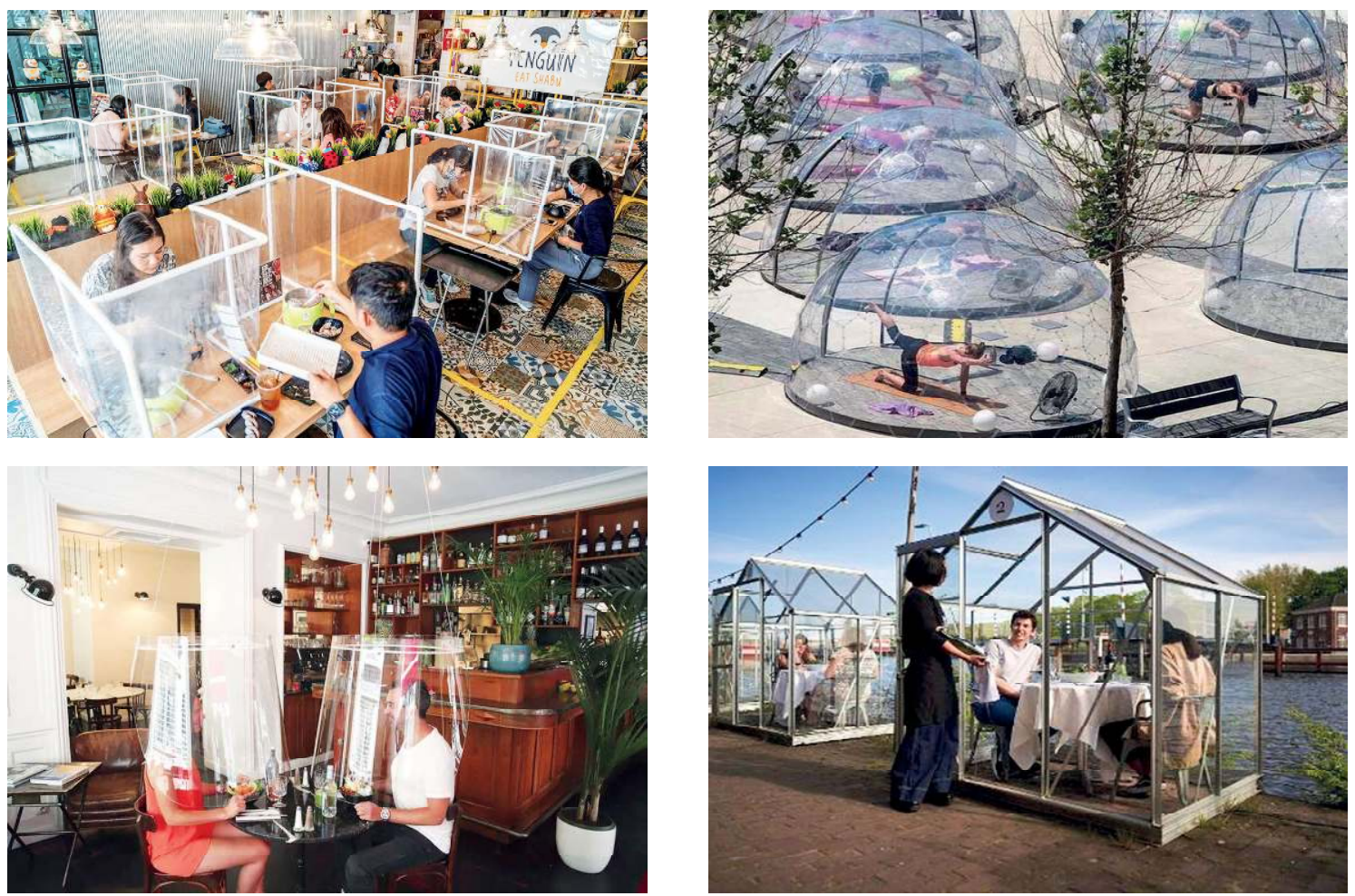

Fontes: Exame, Casa Vogue, Globo, Bons Fluidos, 2020.

E Sociológico $\quad$ Figura 3.
N. ${ }^{3} 39$ (II Série, 2021)
pp. $31-41$ 
Figura 4 Mobilizações sociais de conscientização e distribuição de alimentos no Complexo do Alemão, realizadas pelo Gabinete do Alemão (iniciativa da sociedade civil).

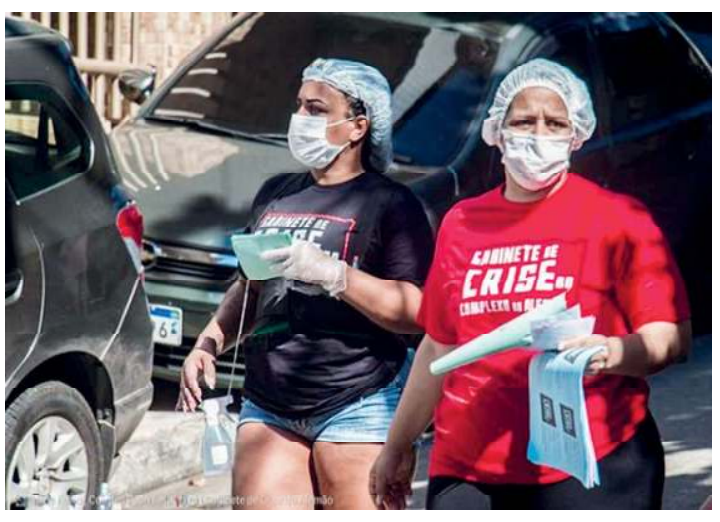

Fonte: Coletivo Papo Reto, mai. 2020.

Para Rolnik, as resistências vêm de práticas e vivências de uma organização social pautada pela solidariedade - e não pelo individualismo - numa busca pelo comum, que estejam menos ligadas ao modo de organização predominante dos séculos XIX e XX. "A normalidade que temos que ansiar não é a que tínhamos, mas um novo sistema que priorize a vida" (Rolnik e Wisnik, 2020).

Como anunciou Harari (2020), todo momento de crise se apresenta como oportunidade de fazermos escolhas que irão determinar o futuro da humanidade. Seja como for, o que traçamos até aqui são meras especulações. Estamos ainda em meio a um longo processo, que nem mesmo acabará com o fim desta pandemia. Até agora, o desenvolvimento das vacinas se apresenta apenas como o começo do fim. Mas será que presenciaremos um fim? Será que haverá o fim de todas as transformações sociais, econômicas e tecnológicas que este cenário pandêmico trouxe consigo? É possível pensarmos, ao final da pandemia, em um retorno ao tão saudosamente invocado "normal"? Para onde, o caminho que estamos tomando, nos levará?

\section{Notas}

Sobre a doença: O que é Covid-19, Ministério da Saúde, Brasil, 2020. Disponível em: https://coronavirus.saude. gov.br/sobre-a-doenca\#o-que-e-covid. Acesso em: 04 nov. 2020.

2 A OMS afirma que Covid-19 é caracterizada agora como pandemia, Unas-SUS, Brasil, 11 mar. 2020. Disponível em: https://www.unasus.gov.br/noticia/organizacao-mundial-de-saude-declara-pandemia-de-coronavirus. Acesso em: 03 nov. 2020

3 Calendário da vacinação contra a Covid-19 pelo mundo: veja cronograma dos primeiros países a vacinarem, G1, Brasil, 05 dez. 2020. Disponível em: https://g1.globo. com/bemestar/vacina/noticia/2020/12/05/calendario-da-vacinacao-contra-a-covid-pelo-mundo-veja-cronograma-

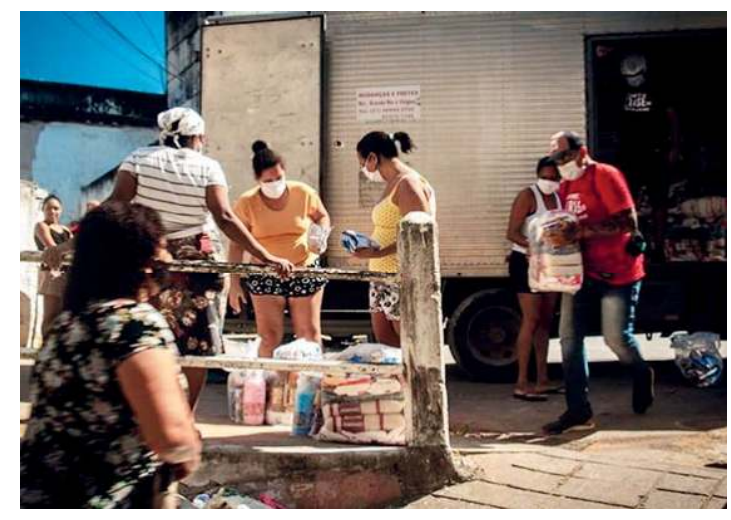

-dos-primeiros-paises-a-vacinarem.ghtml. Acesso em: 05 dez. 2020.

4 Entenda como 15 países em cinco continentes dominaram a pandemia, G1, Brasil, 17 jun. 2020. Disponível em: https://g1.globo.com/mundo/blog/sandra-cohen/ post/2020/06/17/entenda-como-15-paises-em-cinco-continentes-dominaram-a-pandemia.ghtml. Acesso em: 16 dez. 2020.

O xadrez global da pandemia: entre as diversas estratégias de combate à disseminação da doença, resultados de alguns países chamam a atenção, Nexo Jornal, Brasil, 29 nov. 2020. Disponível em: https://www.nexojornal.com. br/externo/2020/11/30/O-xadrez-global-da-pandemia. Acesso em: 16 dez. 2020.

O que os países estão fazendo para controlar a pandemia do coronavírus, Estadão, Brasil, 16 mar. 2020. Disponível em: https://saude.estadao.com.br/noticias/ geral,o-que-os-paises-estao-fazendo-para-controlar-a-pandemia-do-coronavirus,70003235232. Acesso em: 17 dez. 2020.

5 Com o intuito de compreender essa relação imunitária, Preciado (2020) expõe a distinção entre comunidade (o comum - cum munus) e o imune (immunitas, aquele que nega o munus - o comum). Portanto, tornar-se imune é também se abster da obrigação do comum, para além de uma questão biológica; é uma ação político-social entre corpos e comunidades. Sendo assim, a biopolítica é igualmente imunológica através dos dispositivos de controle e da oposição que se estabelece entre grupos de uma mesma sociedade.

6 Possivelmente, o número de casos positivos notificados é menor do que o real, já que há um maior estímulo à contagem de óbitos que à de casos suspeitos, além de subnotificação nas periferias, onde os índices de mortalidade para outras causas são maiores do que em outras partes do município.

7 Coronavírus: Senado aprova auxílio emergencial de $R \$$ 600. Senado notícias, Brasil. 30 mar. 2020. Disponível em: https://www12.senado.leg.br/noticias/materias/2020/03/30/coronavirus-senado-aprova-auxilio-emergencial-de-r-600. Acesso em: 16 dez. 2020. 
8 OMS responde a Bolsonaro e nega que seja contra políticas de isolamento. UOL, Brasil. 31 mar. 2020. Disponível em: https://noticias.uol.com.br/colunas/ jamil-chade/2020/03/31/oms-responde-a-bolsonaro-e-nega-que-seja-contra-politicas-de-isolamento.htm. Acesso em: 16 dez. 2020

9 Veja o que Bolsonaro já fez para confrontar medidas de combate ao coronavírus, Folha de São Paulo, Brasil. 30 mar. 20202. Disponível em: https://www1.folha.uol.com. br/poder/2020/03/veja-o-que-bolsonaro-ja-fez-para-confrontar-medidas-de-combate-ao-coronavirus.shtml. Acesso em: 16 dez. 2020.

Governo Bolsonaro impõe apagão de dados sobre a covid-19 no Brasil em meio à disparada das mortes. El País, Brasil, 6 jun. 2020. Disponível em: https://brasil. elpais.com/brasil/2020-06-06/governo-bolsonaro-impoe-apagao-de-dados-sobre-a-covid-19-no-brasil-em-meio-a-disparada-das-mortes.html. Acesso em: 12 dez. 2020.

10 O "encontro" e a "troca", instrumentos fundamentais do capitalismo, foram responsáveis pelas primeiras transmissões do vírus entre a Elite, população residente das áreas nobres de São Paulo (epicentro da covid-19 no Brasil). Assim, para o capital sair "vivo" da crise econômica provocada pelo isolamento, se instala um processo de "sacrifício necessário" da população (Volochko, 2020, p. 39). Essa população é essencialmente periférica, já que, segundo Carlos, "[...] o simples ato de ficar em casa ou ter acesso aos tratamentos em hospitais - em um país como o nosso - não está posto para todos, pois os direitos não são iguais" (p. 14, 2020, grifo nosso). O trabalhador periférico, obrigado a se deslocar das áreas nobres às periferias diariamente, que não possui "direito à quarentena" e sem consciência da sua participação nesse processo, transforma a periferia em um ambiente favorável à disseminação do vírus, contribuindo para a grande discrepância entre número de casos confirmados e número de fatalidades e acelerando a crise social urbana. Esse processo de altas taxas de exploração do trabalho, que garante uma alta concentração da riqueza produzida pelas classes mais ricas, somado à maior exposição aos riscos sanitários, escancara a "descartabilidade do corpo do trabalhador e a permanência da integridade dos privilégios das classes dos capitalistas/proprietários" (Padua, 2020, p. 85).

11 Cabe lembrarmos aqui o quanto os aplicativos de delivery cresceram com a pandemia. Com a necessidade de evitarmos aglomerações, vários restaurantes precisaram ser fechados ao público. Isso não impediu de continuarem vendendo os seus produtos, agora não mais consumidos dentro dos estabelecimentos, mas entregues em domicílio. Mas a possibilidade do trabalho remoto e distanciado não foi - e nem está sendo - uma realidade para todos no Brasil. Com a precarização das relações de trabalho e o aumento dos índices de desemprego, que também a pandemia veio agravar, uma das poucas alternativas disponíveis para a população de baixa renda e baixo grau de escolaridade foi o trabalho através dos aplicativos de delivery - como Ifood, Rappi e Uber Eats.

\section{Referências bibliográficas}

Bauman, Z. (ed.) (2001). Modernidade líquida. Rio de Janeiro: Zahar.

Bauman, Z. (ed.) (2014). Vigilância líquida: Diálogos com David Lyon. Rio de Janeiro: Zahar.
Beiguelman, G. (ed.) (2020). Coronavida: Pandemia, cidade e cultura urbana. São Paulo: ECidade.

Carlos, A. F. A. (ed.) (2020). A "revolução" no cotidiano invadido pela pandemia. Em COVID-19 e a crise urbana (p. p10-17). São Paulo: FFLCH/ USP. Retirado de http://geografia.fflch.usp.br/ sites/geografia.fflch.usp.br/files/Covid_19_e_a_ Crise_Urbana_v7.pdf.

Danner, F. (2011). Biopolítica e liberalismo: A crítica da racionalidade política em Michel Foucault. (Tese de doutoramento). Pontifícia Universidade Católica do Rio Grande do Sul, Porto Alegre. Retirado de http://tede2.pucrs.br/tede2/handle/tede/2874.

Deleuze, G. (ed.) (2005). Foucault. São Paulo: Brasiliense.

Foucault, M. (1995). O sujeito e o poder. Em H. Dreyfus \& P. Rabinow (Eds.), Michel Foucault. Uma trajetória filosófica: Para além do estruturalismo e da hermenêutica (pp. 231-249). Rio de Janeiro: Forense Universitária.

Foucault, M. (ed.) (1999a). Vigiar e punir. Petrópolis: Vozes.

Foucault, M. (ed.) (2005). Em defesa da sociedade. São Paulo: Martins Fontes.

Foucault, M. (ed.) (2019). Sobre a história da sexualidade. Em Microfísica do poder (pp. 363-406).

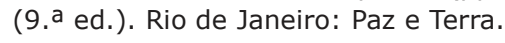

Gonçalves, D. L. C. (2018). Soberania, disciplina e segurança: Uma análise do dispositivo e suas possíveis vertentes em Michel Foucault. Sapere aude, 9(18), 266-284. DOI: 10.5752/P.2177-6342.2018v9n18p266-284.

González, G. Y. (2020). Fragilidad y tiranía (humana) en tiempos de pandemia. Em G. Agamben, S. Zizek, J. L. Nancy, F. B. Berardi, S. L. Petit, J. Butler, A. Badiou, D. Harvey, B.-C. Han, R. Zibechi, M. Galindo, M. Gabriel, G. Y. González, P. Manrique \& P. B. Preciado (eds.), Sopa de Wuhan: Pensamiento contemporáneo en tiempos de pandemias (pp. 139-144). Editorial ASPO. Retirado de https:// bit.ly/sopadewuhan.

Harari, Y. (2020). Notas sobre a pandemia: E breves lições para o mundo pós-coronavírus. São Paulo: Companhia das Letras.

Padua, R. F. (2020). Precarização da vida e redes de solidariedade. Em A. F. A. Carlos (ed.), COVID-19 e a crise urbana (pp. 84-91). São Paulo: FFLCH/ USP. Retirado de http://geografia.fflch.usp.br/ sites/geografia.fflch.usp.br/files/Covid_19_e_a_ Crise_Urbana_v7.pdf.

Preciado, P. B. (2020). Aprendiendo del virus. Em G. Agamben, S. Zizek, J. L. Nancy, F. B. Berardi, S. L. Petit, J. Butler, A. Badiou, D. Harvey, B.-C. Han, R. Zibechi, M. Galindo, M. Gabriel, G. Y. González, P. Manrique \& P. B. Preciado (eds.), Sopa de Wuhan: Pensamiento contemporáneo en tiempos de pandemias (pp. 163-185). Editorial ASPO. Retirado de https://bit.ly/sopadewuhan.

Rolnik, R., Wisnik, G. (2020, 13 de maio). Utopias e distopias em tempos de pandemia. (Seminá- 
rio de Cultura e Realidade Contemporânea) [Vídeo]. Escola da Cidade. Retirado de https://www.youtube.com/watch? $v=31$ sXhys8qe8.

Simoni, C. (2020). Covid-19 e o direito à cidade dos pobres no Brasil. Em A. F. A. Carlos (ed.). COVID-19 e a crise urbana (pp. 24-25). São Paulo: FFLCH/ USP. Retirado de http://geografia.fflch.usp.br/
sites/geografia.fflch.usp.br/files/Covid_19_e_a Crise_Urbana_v7.pdf.

Volochko, D. (2020). O cotidiano dos pobres não pode parar: A pandemia e a necrodemografia do capital. Em A. F. A. Carlos (ed.), COVID-19 e a crise urbana (pp. 35-41). São Paulo: FFLCH/USP. Retirado de http://geografia.fflch.usp.br/sites/geografia.fflch. usp.br/files/Covid_19_e_a_Crise_Urbana_v7.pdf.

Esta obra está licenciada com uma Licença Creative Commons Atribuição - 4.0 (CC BY 4.0).

Recebido a 25/05/2021. Aceite para publicação a 27/10/2021.

Beatriz Fernanda Carvalho. Universidade de São Paulo, Instituto de Arquitetura e Urbanismo, São Carlos, São Paulo, Brasil. ORCID: https://orcid.org/0000-0002-1045-3228. Email: beatrizfc@usp.br

Heloisa Alexandre Cizeski. Universidade de São Paulo, Instituto de Arquitetura e Urbanismo, São Carlos, São Paulo, Brasil. ORCID: https://orcid.org/0000-0002-0558-2156. Email: heloisacizeski@usp.br

Stephanie Tomé Lobozzo Dower. Universidade Estadual Paulista, Faculdade de Ciências e Tecnologia, Departamento de Planejamento, Urbanismo e Ambiente, Presidente Prudente, São Paulo, Brasil. ORCID: https:// orcid.org/0000-0001-6730-8710. Email: stephanie.dower@outlook.com

Inayara Santos Sampaio. Universidade de São Paulo, Instituto de Arquitetura e Urbanismo, São Carlos, São Paulo, Brasil. ORCID: https://orcid.org/0000-0002-0334-9596. Email: inayara.sampaio@usp.br

Bárbara Pozza Scudeller. Universidade de São Paulo, Instituto de Arquitetura e Urbanismo, São Carlos, São Paulo, Brasil. ORCID: https://orcid.org/0000-0003-2859-7884. Email: barbara.scudeller@usp.br 